\title{
Workfare in Germany and the Problem of Vertical Fiscal Externalities
}

\author{
HOLGER FEIST and RONNIE SCHÖB \\ $C E S$ - Center for Economic Studies \\ Ludwig-Maximilians-Universität München \\ Schackstr. 4, D-80539 München \\ Email: holger.feist@ces.vwl.uni-muenchen.de \\ Revised version, February 1999
}

\begin{abstract}
Social assistance to the poor is increasingly subject to compulsory work requirements in Germany. Municipalities have started to offer temporary employment in their job-creation companies to claimants who are able to work. These claimants earn wages and social insurance contributions if they accept the offer, but lose social assistance if they reject it. Further savings to local funds arise from the fact that when a worker's temporary employment ends, he or she is entitled to federal unemployment benefits which involve no costs for the municipality. The paper analyses this vertical fiscal externality and shows that in the long run, municipalities tend to employ a suboptimal number of welfare recipients in their companies.
\end{abstract}

JEL Classification: H 53, D 81

Key Words: $\quad$ Social assistance, Unemployment insurance, Fiscal federalism

* We are grateful to Helge Berger, Jeremy Edwards, Sheilagh Ogilvie, Ulrich Scholten, Hans-Werner Sinn, Marcel Thum and two anonymous referees for their helpful comments. 


\title{
Workfare in Germany and the Problem of Vertical Fiscal Externalities
}

\author{
HOLGER FEIST and RONNIE SCHÖB
}

\section{Introduction}

The dramatic rise in unemployment in Germany since the early 1990s has created a crisis in the social assistance program, which is the lowest layer in the German social safety net. Those mainly affected by this crisis are the municipalities, which are responsible for most social security measures outside the social insurance system. Social assistance expenditures are primarily financed by the municipalities themselves, which do not receive public compensation from the central government as a strict application of the "principle of connexity" (Konnexitätsprinzip) would imply. The principle of connexity requires that the delegation of tasks by the federal government have to be accompanied by sufficient federal funds. As a consequence, municipal budgets are becoming seriously depleted by social assistance expenditures, and the scope for local expenditure programs has been reduced. The call for a comprehensive reform of local government finance has been largely ignored and consequently an increasing number of local governments have started to help themselves by looking for novel ways of restoring their financial independence.

Some municipalities have started to replace the existing social assistance system, in which payments are made unconditionally to all welfare recipients, by a mutual contract in which welfare payments are granted only conditional upon a service rendered in return by the 
recipient. ${ }^{1}$ In practice, municipalities now pay social assistance only to those welfare recipients who are either willing to work or unable to do so. Municipalities such as Leipzig, Frankfurt and Lübeck have started to offer social transfer recipients temporary employment in municipality-owned job-creation companies (so-called "Beschäftigungsgesellschaften") in which they are paid a wage income and have social insurance contributions paid on their behalf. Welfare recipients who turn down such a job offer lose their welfare payments.

The municipalities profit from this change in the social assistance system in several ways. Firstly, the output produced in the local job-creation company increases the amount of publicly provided goods. Secondly, municipalities save on social assistance payments in the short run for all claimants who are able but not willing to work, since these persons lose their entitlements to social assistance transfers. Thirdly, the local authorities save social assistance payments in the long run for those who become temporarily employed in the job-creation company. After having been employed for a year, each worker acquires claims to federal unemployment benefits which the "Bundesanstalt für Arbeit" - a federal, rather than a local, authority - has to pay after the temporary employment contract ends. However, these longterm savings for communities create additional expenditures for the federal government agency. Hence, for the economy as a whole they are not savings but a cost-shifting from the local to the federal government. This vertical fiscal externality caused by the system of social assistance in Germany is the subject of the present paper.

The growing need for German municipalities to look for new ways of reducing their social assistance expenditures is discussed in the next section, which reviews their financial situation. Section 3 presents a case study of Leipzig, which has found a way out of its financial crisis by establishing a local job-creation company. A formal model showing the conditions under which such an institution is advantageous for a municipality and the economic consequences it has is presented in Section 4. The final section comments on recent proposals for the reform of the system of social assistance and unemployment insurance in Germany.

\footnotetext{
${ }^{1}$ See Rosenfeld (1997) for a discussion of the circumstances under which such contracts are justifiable.
} 


\section{Some aims and problems of municipal job-creation companies}

\subsection{The financial crisis of the municipalities}

The structure of the German social security system assigns an unenviable role to the municipalities. The federal law concerning social assistance (Bundessozialhilfegesetz, BSHG) regulates the content and extent of transfers to the poor. Although the BSHG assigns responsibility for implementing the program to state and municipal governments, the latter enjoy very little autonomy in making decisions regarding admission to the program or in designing program features. Welfare programs are mainly financed by state governments, which in turn can determine the extent to which the municipalities also have to make a financial contribution. ${ }^{2}$ The only financial contribution made by the federal government is to the payments for immigrants, refugees, and Germans living abroad. In short, the law is defined by the federal government, but its execution and financing is the responsibility of state and, in particular, municipal governments.

The sharp increase in social assistance expenditures over the last two decades has brought the financial situation of municipalities close to the point of disaster. The expenditures on regular social assistance ("Laufende Hilfe zum Lebensunterhalt"), which is granted to households if their income or wealth is not sufficient to cover subsistence, amounted to 20.2 billion deutschmarks in 1997. This was more than four times the level of 1980. By comparison, total local expenditures have risen only about $92 \%$ in the same period. Figure 1 shows the timing of this process as well as the significance of the problem for local government finance. ${ }^{3}$

\footnotetext{
${ }^{2}$ States provided one-third and municipalities two-thirds of social assistance expenditures in 1993 (see also Klanberg and Prinz, 1984). Wieland (1996) points to a gap in the German fiscal constitution concerning the relationship between the federal government and the municipalities which leads to a delegation of tasks by the federal government which are not accompanied by sufficient federal funds, as the principle of connexity (see e.g. Biehl, 1996) would require.

${ }^{3}$ For a concise description of this development, see Deutsche Bundesbank (1996) and Seitz and Kurz (1998).
} 
Figure 1: The development of social assistance expenditures

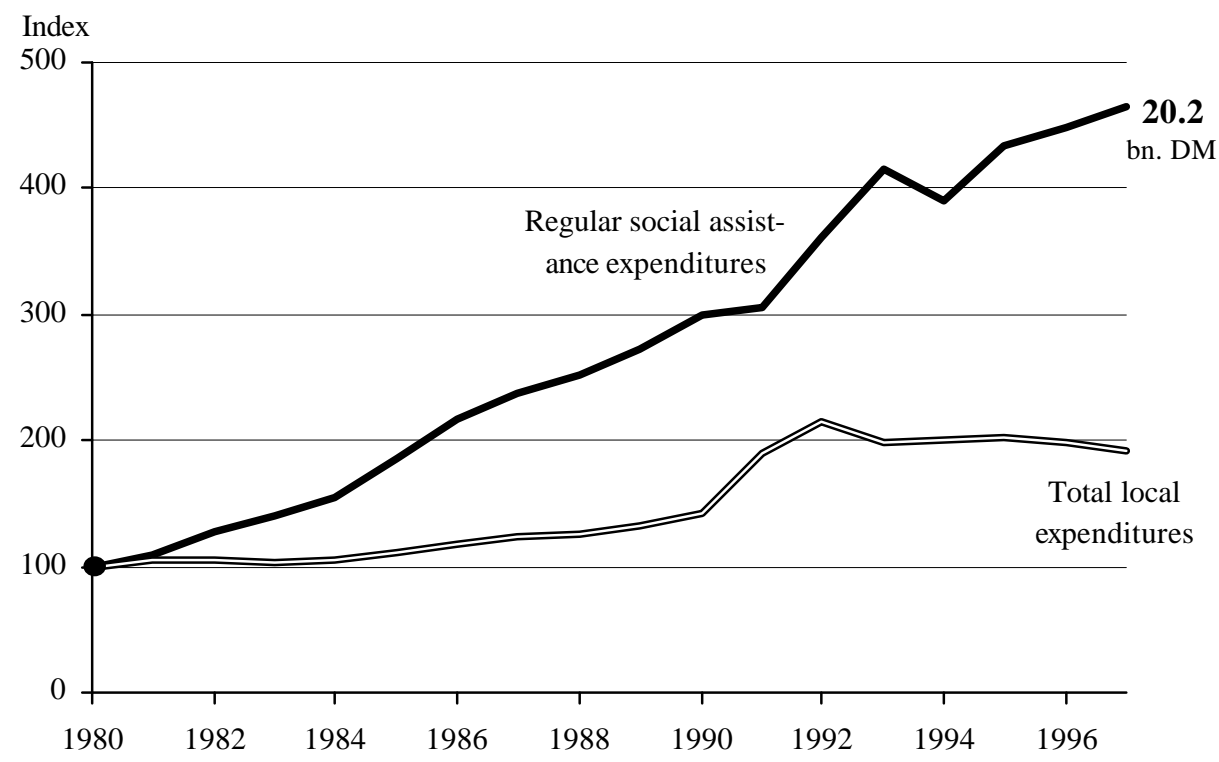

Notes: Expenditures on regular social assistance (Laufende Hilfe zum Lebensunterhalt) are the share of total social assistance expenditures (44.4 bn deutschmarks in 1997) which is mainly borne by municipalities. By definition, they do not include expenditures on assistance in special situations (Hilfe in besonderen Lebenslagen, which totalled 24.2 bn deutschmarks in 1997). Total local expenditures consist of the aggregate expenditures of municipalities (Gemeinden and Gemeindeverbände), including social assistance expenditures. The increase in total local expenditures in 1991 is mainly due to German unification, which had a delayed effect on social assistance expenditures due to transitional provisions. The index is normalized to 100 for 1980 in both time series.

Sources: Statistisches Bundesamt: Fachserie 13, Sozialleistungen, Reihe 2, Sozialhilfe 1996; Statistisches Bundesamt: Statistisches Jahrbuch, various volumes.

The various minor reforms of the past few years have had little success in slowing down the rise in social assistance expenditures. ${ }^{4}$ True, the explosion in expenditures has been contained for individual assistance in special situations ("Hilfe in besonderen Lebenslagen") such as disability, which is mostly financed and administered by state-level organizations. For regular social assistance, however, municipalities still have to cope with rapidly rising expenditures.

The main reason for this continual rise is the growing number of recipients. While in 1980 , only $1.4 \%$ of the German population received regular social assistance, by the end of 1996 it was $3.3 \%$ or 2.7 million persons. This development can be ascribed mainly to the sharp rise in unemployment. Strecker (1995, p. 267) reports an increase in the proportion of

\footnotetext{
${ }^{4}$ The most important measures were the covering of the costs of care by the newly installed care insurance in two stages in 1993 and 1997, the redefinition of grants to asylum seekers through the new "Asylbewerberleistungsgesetz", and the prolongation of the period in which long-term unemployment insurance payers who then became unemployed are entitled to unemployment assistance.
} 
households receiving social assistance due to unemployment from $20.3 \%$ in 1983 to $30.3 \%$ in 1993. In absolute terms, this translates into 567,000 households containing a total of 911,000 persons (also see Hauser 1997, p. 524). This dramatic growth in expenditures on social assistance has led municipalities to seek new ways out of their financial crises.

\subsection{The Leipzig example: a case study of a job-creation company}

The Leipzig social affairs department offers temporary employment in the municipality-owned company "Betrieb für Beschäftigungsförderung" (BfB) to every social assistance claimant who is considered able to work. ${ }^{5}$ If the claimant rejects the offer, his or her social assistance entitlements are cut in three stages, until they are removed completely. If the claimant accepts the offer, he or she receives a temporary one-year contract from the BfB. The contract guarantees an average net income of about 1,400 deutschmarks per month. This salary is higher than the social assistance payment, which is on average slightly below 1,000 deutschmarks, but it amounts to only about $80 \%$ of the wage of the lowest wage-group agreed on for public servants. ${ }^{6}$ The wage offered by the job-creation company rewards work, given the threat to cut assistance otherwise, ${ }^{7}$ and creates an entitlement to social insurance payments in future. In addition, those who are willing to work enjoy some non-pecuniary advantages such as a reduction in stigmatization as a jobless person and the (re-) learning of certain basic skills essential for competing for ordinary jobs. ${ }^{8}$ Workers in the job-creation company can also

\footnotetext{
${ }^{5}$ In determining a person's ability to work, the city of Leipzig makes use of the entire range of possibilities defined by legislators in $\S 19$ and $\S 20$ of the BSHG. According to these paragraphs there is to be no recruitment of people who are physically or mentally unable to work, in cases where recruitment would affect the education of a child, and in those where it would significantly reduce the person's future ability to exercise a former longstanding occupation.

${ }^{6}$ In the $\mathrm{BfB}$, wages are partially determined by the size of the workers's family, as is the case with the social assistance level. This feature clearly marks the $\mathrm{BfB}$ as a charitable organization rather than a private corporation.

${ }^{7}$ It is not self-evident that social assistance recipients benefit from accepting a low paid job in the regular labour market. In the current German system, the implicit marginal tax rate is still up to $100 \%$ for a wide range of earned incomes, so that additional work effort has no attraction whatsoever; see Feist (1996).
}

${ }^{8}$ See Winkelmann and Winkelmann (1995) and Gerlach and Stefan (1996). 
participate in its program for obtaining skills qualifications so that, over all, the chances of finding an occupation on the regular job market should improve. ${ }^{9}$

The BfB in Leipzig tries to adjust to the wishes and capabilities of individual claimants, but the majority of jobs are physically demanding, unpleasant tasks, such as turning waste land into building land, dredging the mud out of ponds, or removing toxic construction materials from houses. The company has its own laundry, printing works, various workshops, a market gardener, and a nursery.

Figure 2: The Leipzig model of a job-creation company

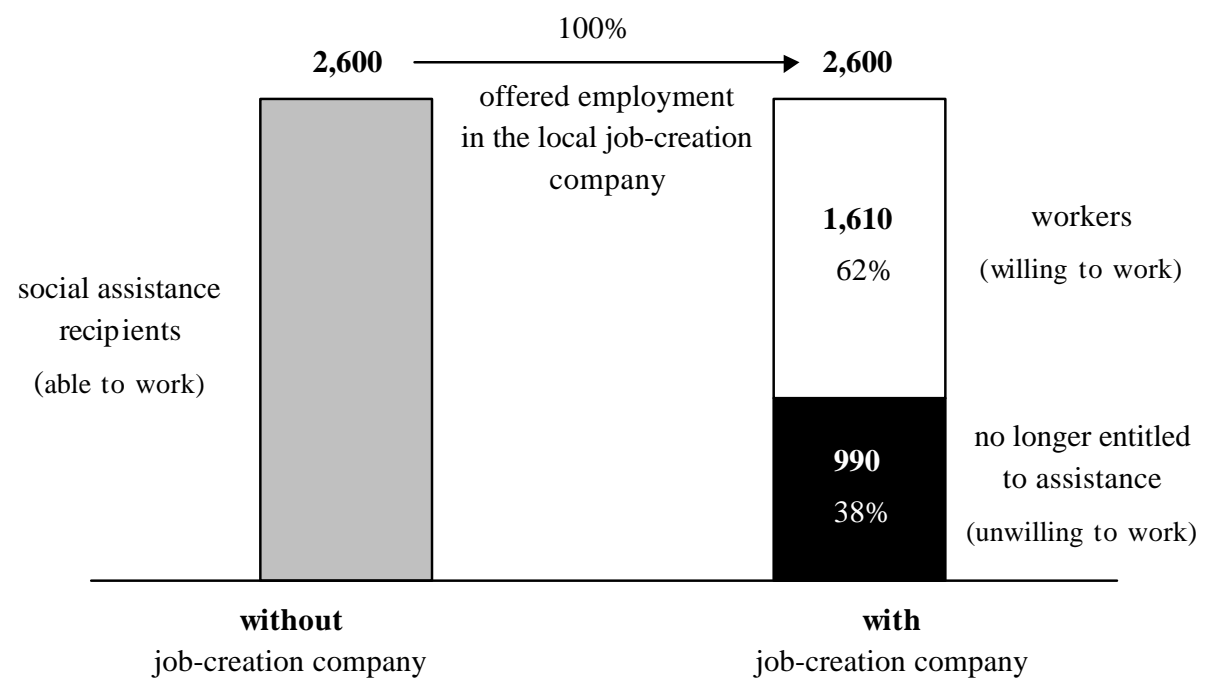

Source: Statements by the Betrieb für Beschäftigungsförderung, Leipzig, cited as in Kirbach (1997).

Figure 2 shows the situation in Leipzig before and after the establishment of the job-creation company. The city systematically offered a job to each of the approximately 2,600 social assistance recipients considered to be able to work. Of these, only $62 \%$ or about 1,600 persons accepted the job offer. ${ }^{10}$ The other $38 \%$ had to face a significant cut in social assistance or

\footnotetext{
${ }^{9}$ However, in 1996 only $8 \%$ of the workers employed by the BfB managed to find an occupation in the regular job market.

${ }^{10}$ Although all social assistance recipients were offered a job in 1996 and all contracts were limited to one year, the number of employees in September 1997 was still 1,400 persons. This can be explained by the fact that the number of social assistance claimants grew by about $40 \%$ in 1997 due to the adverse labor market situation, the end of transitional arrangements in the course of German unification, and a better understanding by the poor of the options open to them (telephone information provided by the Leipzig social affairs department, October 21, 1998).
} 
even its discontinuation. For the city of Leipzig, the departure of so many welfare recipients meant an immense fiscal surplus, out of which a non-negligible fraction of the employment contracts, which are more expensive than pure welfare payments, could be financed. ${ }^{11}$

Alas, this is not the entire story. The second half of the Leipzig saga cannot be found in the brochures published by the municipal government. The city of Leipzig obtains much more significant savings through this welfare program because all temporary workers in the jobcreation company cease to burden the coffers of the municipalities, either partially or wholly. Having paid social security contributions for 360 calendar days, these workers are entitled first to receive unemployment benefit payments for 156 calendar days at a level equal to $60-67 \%$ of their previous net wage, and then - conditional on fulfilling requirements such as compulsory registration with the federal government's job agency, remaining available for employment, working toward skills qualifications, etc. - to be paid indefinite unemployment assistance amounting to $53-57 \%$ of their previous net wage. The former benefits are financed by social insurance contributions, while the latter are administered by a federal agency and financed with federal funds. In this way, benefit payments are shifted from the municipal to the federal government. In cases such as this, local social assistance, as the safety net below unemployment insurance and unemployment assistance, will only fill the gap up to the subsistence level.

\subsection{Fiscal consequences of a job-creation company}

How should the economic consequences of a job-creation company be judged, if the burdenshifting effect is taken into account? This question can hardly be analyzed adequately using existing models in the economics literature on fiscal federalism. Most models of fiscal expenditure externalities concentrate on what happens if individual municipalities can

\footnotetext{
${ }^{11}$ The average social assistance transfer for single persons, of about 1,000 deutschmarks per month, disppears for $38 \%$ of the 2,600 previous recipients, leading to savings of about 1 million deutschmarks. Labor costs have to be paid for the $62 \%$ of the previous recipients who now receive wage income and for whom Leipzig has to pay wage taxes and social security contributions. In total, Leipzig has to pay about 1,280 deutschmarks more for a worker than it has to pay for welfare recipient. About half of the additional expenditures which amount to 2 million deutschmarks per year, can be compensated for through savings from vanishing recipients.
} 
independently determine the amount of money spent on a specific type of expenditure such as social welfare payments. For these cases, it has been shown that local governments choose an inefficiently low level of expenditures, since expenditures on local welfare programs attract poor mobile households from other municipalities and drive rich households out of the home municipality. This form of horizontal competition among jurisdictions is discussed in Musgrave (1971), Brown and Oates (1987), Wildasin (1991) and Sinn (1994, 1997). However, within Germany horizontal competition is of negligible importance since the German system of social assistance is relatively homogeneous due to federal regulations. Even the creation of municipality-owned job-creation companies will hardly lead to an increase in horizontal fiscal competition, since the law provides that a municipality begins to pay for a welfare recipient only two years after he or she has taken residence in this municipality (cf. $\S \S 97$ and 107 of the BSHG). Until then, the former home municipality remains responsible. Mobility costs for social assistance recipients are sufficiently high so that the incentive to move in order to avoid working in the job-creation program will be very low.

Spillovers from local expenditure decisions onto the federal budget, so-called vertical expenditure externalities, are discussed hardly at all in the literature. ${ }^{12}$ An analysis of recent developments in local expenditure policy, such as the creation of municipality-owned jobcreation companies, and their repercussions on the federal budget, is entirely lacking. The theoretical analysis which follows seeks to close this gap.

\section{The fiscal consequences of establishing a job-creation company}

In the following we consider a model of a federal system consisting of $N$ ex ante identical municipalities and one federal government. The task of the federal government is to levy taxes, to pay unemployment benefits and unemployment assistance, and to forward the rest of the tax revenues as a federal grant to the municipalities, who are not authorized to levy taxes on their

\footnotetext{
${ }^{12}$ Exceptions are Wiegard (1980), Dahlby (1996) and Wrede (1997).
} 
own. ${ }^{13}$ The federal government therefore redistributes income from workers to the unemployed on the one hand, and among different municipalities on the other.

\subsection{A basic model of social assistance}

Each individual municipality is granted a given budget $Z$ which it may use to finance social assistance expenditures or to provide a local public good $G .{ }^{14}$ The number of poor people living in each municipality is exogeneously given as $S$. This number is assumed to be the same for all $n$ municipalities. These poor people are in principle able to work, but are nevertheless entitled to social assistance and receive an annual welfare benefit $b_{n}$. The budget restriction of municipality $n$ is therefore given by

$$
Z_{i}=G_{n}+b_{n} S
$$

The amount of welfare benefit $b_{n}$ can - within certain limits - be determined independently by each individual municipality. However, the municipality has to guarantee at least a sociocultural subsistence income level $m$, a provision guaranteed by the German constitution (see Bundesverfassungsgericht, 1992), i.e. $b_{n} \geq m$.

The local government maximizes the utility of the median voter in the municipality, who is assumed to be a worker. Since no local taxes are levied, the utility of the median voter can only be influenced by the provision of a public good. ${ }^{15}$

\footnotetext{
13 The institutional arrangements of the German system are simplified in this model. All tasks of the intermediate layer of government, that of the states, are assumed to be performed by the federal government. The model also disregards any possibility of municipalities levying taxes on their own.

${ }^{14}$ This assumption implies that the "principle of connexity" does not play a role in social assistance. See Wieland (1996), as well as Münstermann (1998), for state-specific regulations concerning inter-governmental grants.

${ }^{15}$ If a municipality could finance the provision of the public good through municipal taxes it would raise its tax rate until the marginal rate of substitution of private consumption through the public good equalled the marginal cost of public good provision (including the excess burden resulting from the municipal tax). In this case the median voter also has an interest in minimizing the welfare benefit payments to the poor because this keeps his or her municipal taxes low and the provision of the public good high.
} 
From (1) it follows that the municipality will provide welfare benefits exactly at the federally legislated socio-cultural subsistence level, $b_{n}=m$, in order to maximize the amount of the local public good. Municipal expenditures for the local public good then amount to

$$
G_{n}=Z-m S
$$

This is a very stylized description of the existing German social assistance system. By establishing a job-creation company, however, Leipzig has demonstrated that the main tasks of social assistance can effectively be taken over by a system in which only the willingness to work guarantees an entitlement to further financial assistance.

\subsection{Modelling the job-creation company}

To investigate whether the Leipzig model represents a viable alternative to the current system of social assistance, we again examine the calculus of a representative municipality which takes the federal grant $Z$ as given. The local government can decide either to maintain the current system or to establish a local job-creation company and make social assistance dependent on claimants' willingness to work. If a job-creation company is set up, the local government has then to decide how many workers it wants to employ in each period. While first-year employment is determined by hiring only, from the second year on the level of employment can be influenced both by hiring some of the remaining social assistance claimants who are not yet employed and by laying off workers who were employed in the previous year.

By dismissing workers after one year, the municipality gets rid of any future welfare payments to these workers, because these workers have acquired entitlements to federalbudget unemployment benefit and assistance. The municipality derives an additional advantage from establishing a job-creation company. If a claimant rejects the offer of work, he or she is no longer entitled to social assistance. Hence, the local government gains an instrument for sorting out those claimants who are not necessarily dependent on public assistance. Since only a proportion $\alpha \leq 1$ of social assistance recipients take up work, but all claimants who were 
offered a job lose their welfare benefit $m$, the savings per employee of the job-creation company exceed the welfare benefit per recipient by $1 / \alpha$.

The local government maximizes the utility of the median voter by maximizing the local public good $G$ given the budget restriction. Welfare benefit and net wage in the job-creation company are therefore set to the federally legislated socio-cultural subsistence income level. But the operation of the job-creation company involves some additional costs for the municipality, such as social insurance contributions, wage taxes and the costs of providing the workplace. In the following, total expenditures of the company per worker are denoted as the gross wage $w$.

To fill positions in its job-creation company, each year $t$ the municipality offers a job to $H(t)$ of the social assistance recipients. ${ }^{16}$ A proportion $\alpha H(t)$ of the recipients will accept the job offer and start working in the job-creation company. ${ }^{17}$ A proportion $(1-\alpha)$ will reject the offer and loses its entitlement. ${ }^{18}$ For $\alpha<1$, therefore, the work requirement serves as a selection mechanism which ensures that only really needy persons obtain public assistance. ${ }^{19}$ The greater $(1-\alpha)$, the greater is the cost-saving effect for the local budget when additional recipients are offered a job.

The number of employees in the job-creation company in year $t$ is defined as $B(t)$. In the start-up phase of the company, the number of employees depends only on the number of recipients $H(1)$ asked to work in the first year, and on the acceptance rate $\alpha$ :

$$
B(1)=\alpha H(1)
$$

\footnotetext{
${ }^{16}$ In principle, the municipality could also ask the recipients of unemployment assistance to work in its jobcreation company. This case is neglected here because the local government would always prefer hiring a social assistance recipient to hiring an unemployment benefit recipient because of the future cost savings at the expense of the federal budget, which the municipality would enjoy in the former case but not in the latter case.

${ }^{17}$ As shown in Section 2, for Leipzig the proportion of those who accept a job offer is $\alpha=0.62$. Strecker (1995, p. 269) reports that in the city of Cologne, out of 5,000 social assistance recipients who were offered work, only 77 persons rejected the offer. The proportion of persons willing to work in Cologne therefore was $\alpha=0.98$.

${ }^{18}$ The instantaneous loss of all entitlements is a simplification. In Leipzig, welfare benefits are cut in two stages of $25 \%$, and only if a third offer is rejected is the benefit payment set to zero.

${ }^{19}$ See the Anglo-American literature on the question of workfare versus welfare, e.g. Besley and Coate (1992), Dye and Antle (1986), Nichols and Zeckhauser (1982), and Zeckhauser (1971).
} 
Employment in the following years $T=2,3, \ldots$ depends on the number of recipients offered a job, $\sum_{1}^{T} H(t)$, on the acceptance rate $\alpha$, and on the dismissals which the company can carry out from the second year on, $\sum_{1}^{T} F(t)$ with $F(1)=0 .{ }^{20}$ Therefore

$$
B(t)=\sum_{1}^{t}[\alpha H(t)-F(t)]
$$

In the local job-creation company, the local public good $G$ is produced with technology $f(B(t))$, for which we make the common assumptions $f^{\prime}(B(t))>0, \quad f^{\prime \prime}(B(t))<0$, $f^{\prime}(0)>>0$, and $\lim _{B(t) \rightarrow+\infty} f^{\prime}(B(t))=0 .^{21}$

\subsection{Two preliminaries on the choice of system}

Two preliminary considerations allow us to reduce to a minimum the analytical apparatus necessary for explaining the maximization calculus of the municipality. First, it is immediately clear that it is worthwhile for the municipality to hire a new worker as long as his or her marginal product $f^{\prime}$ exceeds the gross wage $w$. After the municipality has shifted all former local social assistance recipients over to the federal unemployment benefits program via the job-creation company, it will still maintain a long-run employment level where the marginal product of the last worker equals the gross wage, so that the condition $w=f^{\prime}$ determines long-run employment. Since employment in the later years is therefore independent of decisions made in the first years, the later years are not considered any further.

A further, more technical assumption will help to determine when the long-run employment level will actually be reached. From the condition that the marginal product of workers converges to zero when the number of workers approaches infinity, $\lim _{B(t) \rightarrow+\infty} f^{\prime}(B(t))=0$, it follows that $w-f^{\prime}(B(t))$, the net burden on the municipal budget from an additional worker, will never be greater than $w$. To reduce the analysis to three periods, it is

\footnotetext{
${ }^{20}$ In practice, workers leaving the job-creation company voluntarily would have to be added, but these are neglected in our theoretical analysis.

${ }^{21}$ The objective of the municipality is to maximize the provision of the public good $G$, the price of which is normalized to unity. Before providing the good, the municipality takes a make or buy decision. The costefficient solution directly follows from the optimal employment level of the job-creation company.
} 
therefore assumed that the wage rate does not exceed double the expected savings, i.e. $w \leq 2 m / \alpha .^{22}$ The length of time before which the municipality has offered a job to all former social assistance recipients is then restricted to three years. If the municipality only offered a job to a recipient in the third year, this would lead to payments of $2 m$ over the first two years. If the municipality offered the job in the first year, however, this would cost it an expected maximum of $\alpha\left[w-f^{\prime}(B(1))\right]$ because it could always lay off the worker in the second period in order that the worker would then receive transfers from the federal government. Hence, since total costs are smaller than $\alpha w$ and by assumption, $w \leq 2 m / \alpha$, total costs in the case when the recipient is employed in the first year are always smaller than those when he or she is employed in the third year. Therefore, the company will hire workers only in the first two years and will reduce employment to the constant long-run level at the latest in the third year. For the model this implies that $H(3)=0$.

\subsection{The calculus of an individual municipality}

These preliminary analytical considerations demonstrate that the calculus of a municipality can be restricted to a period of three years. Leaving discounting aside, the municipality maximizes the provision of the public good $G$ over three years. As discussed above, it can choose the number of persons to whom it offers a job in each year, $H(t)$, or whom it will lay off in each year, $F(t)$ :

$$
\begin{aligned}
\max _{H(1)} G & =G(1)+G(2)+G(3) \\
& =3 Z-m(S-H(1))-m(S-H(1)-H(2))-m(S-H(1)-H(2)-H(3)) \\
& -w\left(\alpha \sum_{1}^{3}[H(t)-F(t)]\right. \\
& +f(\alpha H(1))+f(\alpha(H(1)+H(2))-F(2)) \\
& +f(\alpha(H(1)+H(2)+H(3))-F(2)-F(3))
\end{aligned}
$$

\footnotetext{
${ }^{22}$ As the Leipzig case study has shown, this assumption is not very restrictive. For $m=1,000$ deutschmarks and $\alpha=0.62$ the gross wage has to remain below 3,225 deutschmarks per month. Given that Leipzig offers a net wage of 1,400 deutschmarks, this assumption seems very plausible. Even if the assumption is relaxed, only the adjustment period would become longer without qualitatively changing the results of the paper. If, e.g., $w \leq 3 m / \alpha$ was assumed, it can be shown that it takes three years until all former social assistance recipients are offered a job.
} 
The total amount of the public good provided in these three years depends on the surplus of federal grants over expenditures on social assistance and the gross wages which have to be paid to the employees of the job-creation company, as well as on the amount of the public goods produced there. This maximization problem (5) is subject to various constraints. First, it is impossible to lay off more workers in the second year than have been employed in the first year:

$$
\alpha H(1)-F(2) \geq 0
$$

The term $\lambda_{1}$ indicates the shadow price associated with this condition.

Furthermore, it is impossible to lay off more workers in the third year than have been employed in the second year:

$$
\alpha(H(1)+H(2))-F(2)-F(3) \geq 0 \text {. }
$$

Finally, the number of social assistance recipients cannot become negative:

$$
S-H(1)-H(2) \geq 0 .^{23}
$$

The preliminary analytical considerations showed that all social assistance recipients will be offered a job in the second year at the latest. Since $H(3)=0$, condition (8) is binding. Another result of the preliminary analytical considerations was that employment will never fall below the long-term level which is determined by the condition $w=f^{\prime}$. Since in the third year, employment can only be affected through dismissals, it follows that the local government has no incentive to lay off all employees in the third year, which means that condition (7) is not binding and $\lambda_{2}=0$. Therefore, the first order condition for an optimal level of employment in the third year is

$$
w=f^{\prime}(B(3)) .
$$

\footnotetext{
${ }^{23}$ It is supposed that $S-H(1)>0$ because otherwise, the municipality would chose the same employment level in the second year as in the first year.
} 
This result is not surprising, as it follows directly from the previous conclusion that all social assistance recipients are offered a job in the first two years, and that it does not pay for the municipality to let them go on working if it leads to net local costs. ${ }^{24}$

In Figure 3, the curve $w-f^{\prime}$ indicates the net costs of a worker in the job-creation company, whereas the line $m / \alpha$ shows the expected annual savings in social assistance payments. Condition (9) establishes that the level of employment in the third year, $B(3)$, equals the long-term level of employment $B(\infty)$.

Figure 3: Employment levels in the job-creation company

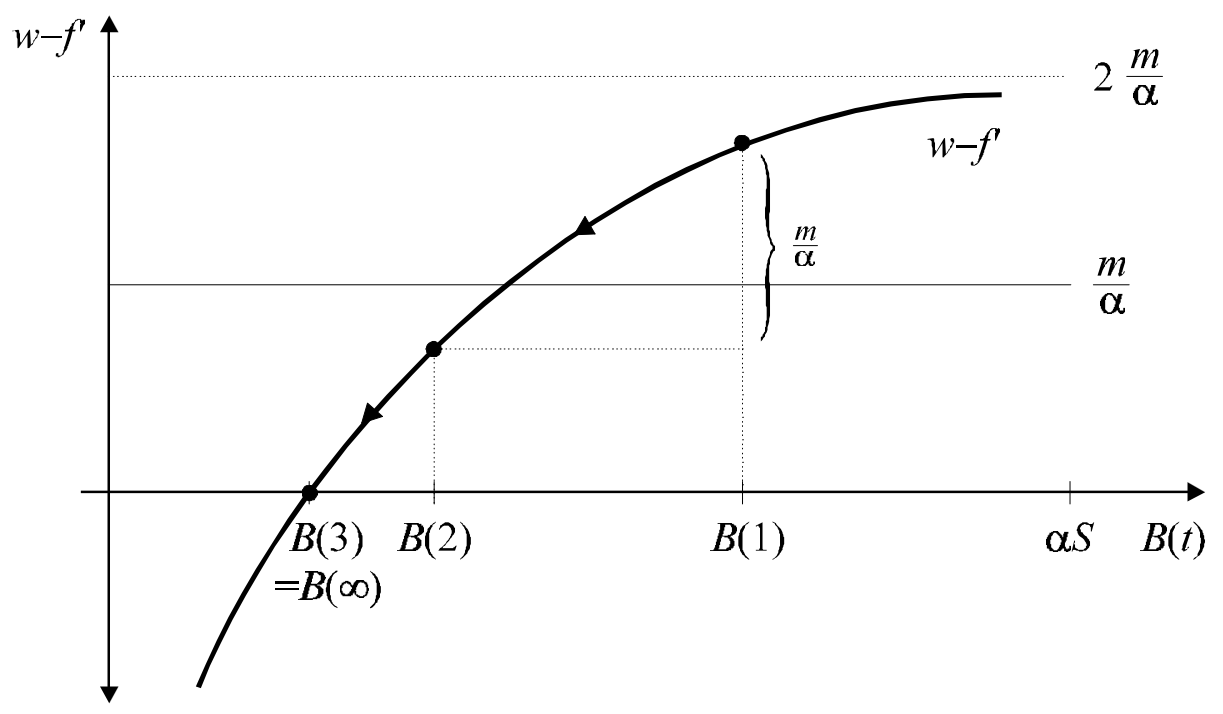

As jobs are offered in the first two years only, the question arises of how many of the $\alpha S$ social assistance recipients who are willing to work will be hired in the first year and how many in the second year. Employing a new recipient in the first year costs the municipality $w-f^{\prime}(B(1))$. Since the municipality can fire the recipient in the second period, no further costs are incurred. The benefit arising from an additional person employed in the first year is equal to the expected saving in social assistance payments in the first year, $m / \alpha$, plus the saving resulting from the fact that the recipient would have to be employed in the second year if he or she was not employed in the first. These savings are equal to the surplus of the gross wage over the

\footnotetext{
${ }^{24}$ If necessary, the municipality might reach this employment level by offering jobs to the recipients of unemployment benefits since this employment level is rewarding for pure profit reasons (cf. footnote 17).
} 
marginal product of the worker in the second year, $w-f^{\prime}(B(2))$. No further costs are incurred in the future, irrespective of whether the worker is laid off in the third year or is permanently employed. In the former case, the federal government has to pay for the worker, while in the latter case, the worker's marginal product will just cover the gross wage he or she receives. Hence, it pays for the municipality to reduce the number of employees in the first year, as long as $w-f^{\prime}(B(1))>m / \alpha+w-f^{\prime}(B(2))$. The employment levels for the first two years are therefore implicitly determined by the first order condition

$$
w-f^{\prime}(B(1))=m / \alpha+w-f^{\prime}(B(2)),
$$

and the conditon

$$
B(1)+B(2)=\alpha S
$$

which follows directly from our preliminary analytical considerations. Because for a given employment level in both periods, the advantage of hiring one additional worker in the first year always exceeds the advantage of hiring the worker in the second year, the second-year employment level in the job-creation company will be lower than that in the first year. Furthermore, the employment level in the second year will always exceed the employment level of third year because of the cost-shifting effect. Hence,

$$
B(1)>B(2)>B(3)=B(\infty)
$$

It pays for the municipality to build up a high employment level at the beginning, in order to shift as many local social assistance recipients as possible to the federal unemployment benefits program. The levels of employment in the second and third year are then reduced, until finally the long-term profit maximizing employment level is reached. However, it should be emphasized that this does not imply that the job-creation company could be organized privately, because the wages it pays to workers are well below the negotiated regulatory wages which private enterprises have to pay. 


\section{Local savings at federal expense}

\subsection{The effect on local budgets}

What is the fiscal advantage to the municipality from these job-creation companies, compared to the conventional system of social assistance in Germany? In the founding year of a jobcreation company, its costs may actually exceed those of the social assistance system, but in later years they are clearly lower. In the long run, the municipality saves money by establishing the job-creation company, as can be seen in Figure 4.

Figure 4: Fiscal effects of a local job-creation company

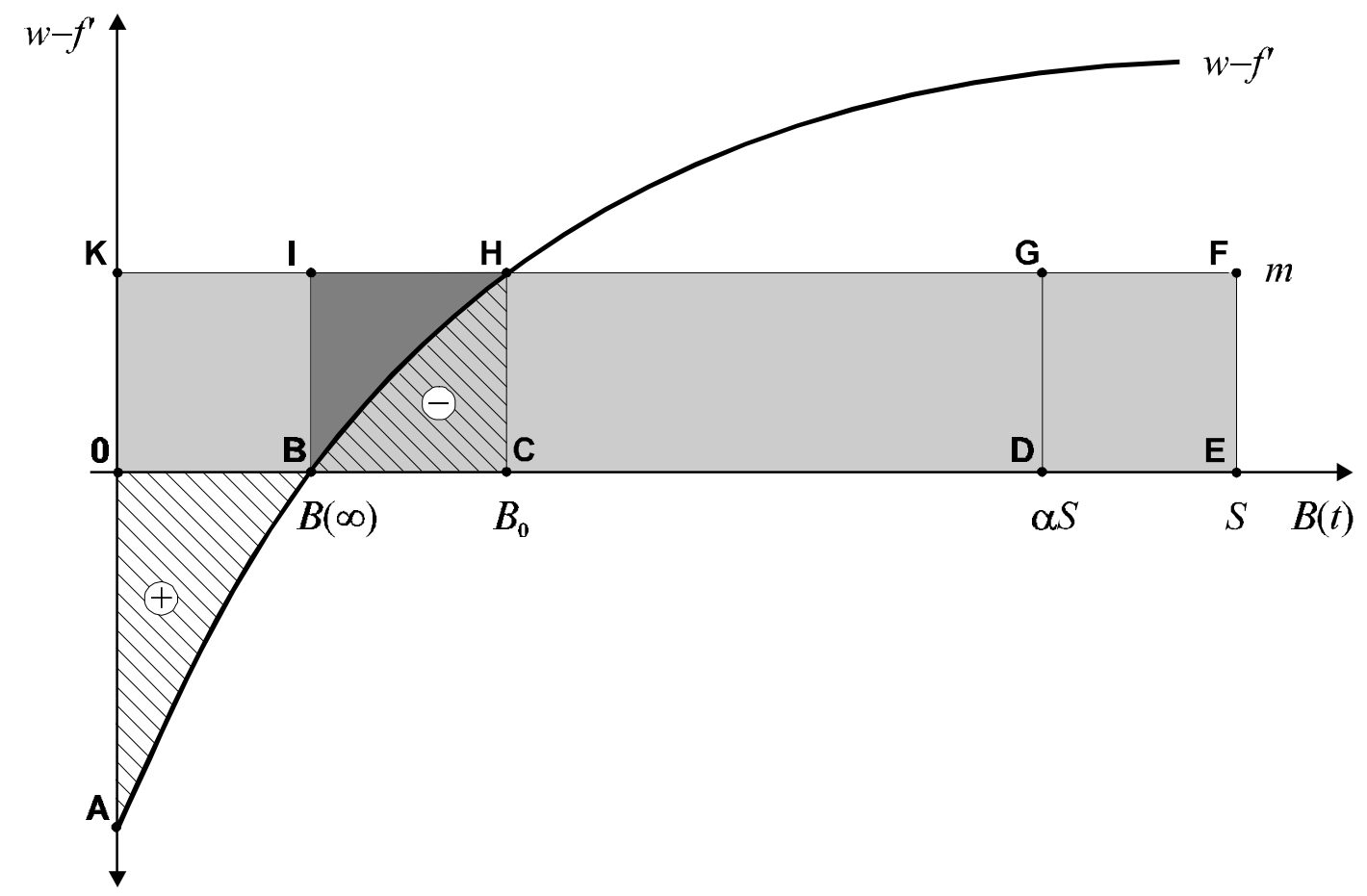

In the traditional welfare system, the municipality has to pay welfare benefits $m$ to all $S$ recipients $(=0 \mathrm{E}$ in Figure 4$)$, equivalent to the area $0 \mathrm{EFK}$. If the municipality decides to replace welfare with workfare and run a job-creation company, in the long run $0 \mathrm{~B}$ workers will be employed in the company, whereas BD former social assistance recipients are shifted to the federal unemployment benefits program through temporary employment contracts. This procedure saves the municipality the amount BDGI. Furthermore, $(1-\alpha)$ social assistance 
recipients (=DE) give up their claim to welfare payments, saving the municipality an additional amount DEFG. The remaining workers $0 \mathrm{~B}$ do not cost the municipalities anything; on the contrary, they create a fiscal surplus of AB0. Permanent annual savings from operating a jobcreation company instead of the traditional social assistance program therefore amount to ABEFK, which is even more than total welfare payments $m S$ were previously.

However, this calculus is correct only if all other municipalities do not change their behaviour. Since every individual one of the $N$ identical municipalities will enjoy the same advantage, they will all switch to workfare. While the effect of a single municipality on the federal budget $Z$ is negligible (for one deutschmark of expenditure shifted to the federal government, a municipality's federal grant is cut by only $1 / N$ ), the situation is different in a Nash equilibrium in which every municipality owns a job-creation company. In this case, the federal grant for each municipality is cut by the amount of the rise in federal unemployment benefit payments, i.e. BDGI. Nevertheless, establishing the job-creation company pays off in the long run since the annual net savings due to the selection effect is still DEFG and the permanently employed former social assistance recipients $\mathrm{OB}$ do not cause any further costs, so that the municipality saves $0 \mathrm{BIK}$. On the contrary, it earns a surplus amounting to $\mathrm{AB} 0$, so that the overall savings effect, compared to the existing welfare system, is ABIK + DEFG.

\subsection{The consequences of vertical fiscal externalities}

The establishment of municipality-owned job-creation companies significantly reduces the municipality's social assistance expenditures. But this does not mean that the current German system in which social assistance is paid by the municipalities and unemployment benefits and unemployment assistance is paid by the federal government, leads local job-creation companies to be operated to a fiscally optimal extent. The vertical fiscal externality generates an incentive for the municipalities to shift too many social assistance recipients to the federal unemployment benefits and assistance programs and keep too few social-assistance recipients in employment. The reason for this is that part of the municipality's savings does not consist of real economic savings, but rather of costs shifted from one public budget to another. 
If the municipalities not only had to pay for social assistance, but also - assuming that their federal grant was adjusted accordingly - for unemployment assistance, their calculus would be entirely different. In the first year, the municipality would employ additional workers as long as their net marginal costs were equal to the expected savings in social assistance, so that $w-f^{\prime}(B(t))=m / \alpha$. Since the municipality is also in charge of unemployment assistance, it would not be able to avoid costs by shifting transfer payment responsibilities to the federal government. The cost of a worker would be reduced only by the amount of the savings in social assistance payments in the current year. If all workers are laid off after one year and new social welfare recipients are offered the jobs, it will not take long before all social assistance recipients who are not willing to work are sorted out. The total number of social assistance (or unemployment assistance) recipients will thus be reduced to $\alpha S$. After that transition period, the long-run employment level will be reduced to $B_{0}>B(\infty)$. As the local government has to pay the socio-cultural subsistence income level in any case, it is now optimal for the municipality to employ workers up to the level where the gross wage minus the marginal product of the worker exactly equals the savings in social assistance payments $m$. The remaining recipients of social assistance, who have not lost their entitlement because they declared themselves willing to work if work was offered, number $\mathrm{CD}$, and continue to receive social assistance $m$.

As compared to a job-creation company in the current system, BC additional workers would be employed. As they no longer receive social assistance payments, this creates savings of BCHI. However, since for this group of workers gross wages do not exceed the marginal product, additional costs $\mathrm{BCH}$ are caused by employing them. Nevertheless, in the (Nash) equilibrium, there is a net improvement $\mathrm{BHI}$ as compared to the establishment of a job-creation company in the current German system. 


\section{Reforming social assistance}

The comparison carried out in the preceding section shows clearly that the establishment of job-creating companies can be considered as a first step in the reform of the social welfare system. The models implemented in Leipzig and certain other German cities show a way in which municipalities can save costs in the current system. The creation of job-creation companies is therefore desirable. However, the vertical fiscal externality inherent in the existing situation requires an additional reform of the current German system of social welfare in which competition in social insurance services between different jurisdictions still prevails. As long as individual municipalities can improve their budgets by shifting the burden to the federal government, less workfare is offered in the long run than would be desirable on grounds of fiscal efficiency. Accordingly, too many claimants remain in the traditional system of unemployment and social assistance, which rewards leisure instead of work (cf. Sinn 1998, p. 53) and destroys a considerable amount of human capital. It is thus necessary to reform the social welfare system in Germany in such a way as to internalize the external effects of local government decisions on the federal government.

Proposals which suggest that social assistance and unemployment assistance be integrated and administered by a single institution point in the right direction. ${ }^{25}$ This would reduce the competition among social insurance services, but would not terminate it entirely. Municipalities would still be able to shift their burden at least temporarily to the Bundesanstalt für Arbeit, the government agency responsible for unemployment insurance which pays benefits during the first year of unemployment. In addition, the problem of establishing a link between the delegation of tasks on the one hand and appropriate grants of funds on the other has not yet been solved (see Wieland 1996). A strict application of the principle of connexity would destroy any incentive on the part of the municipality to save costs in social and

\footnotetext{
${ }^{25}$ See the suggestions by the Christian Democrats who want to assign this task to the municipalities, the suggestions of the Deutscher Städtetag to expand the tasks assigned to the Bundesanstalt für Arbeit, and the suggestions of the Social Democrats who advocate a closer collaboration between local and federal level agencies (see Frankfurter Allgemeine Zeitung dated April 22, 1998, p. 20; Die Welt dated July 9, 1998, p. 2; SPD-Programm für die Bundestagswahl 1998, S. 27).
} 
unemployment assistance programs. It would then be in the sole interest of the federal government to promote the foundation of job-creation companies.

Whenever tasks are delegated to subordinate jurisdictions in the spirit of subsidiarity, it must be guaranteed that subordinate jurisdictions act in the interest of the principal jurisdiction. The increase in social assistance expenditures has forced municipalities to take action on their own. By beginning to replace welfare programs by workfare programs, German municipalities have taken an important step in the direction of a more economical use of scarce public funds. But the fiscal externality involved in the current system requires an additional fundamental reform of transfers to the unemployed, if the aim is to ensure a subsistence level of income in as cost-efficient a way as possible. 
References

Besley, T. J., and S. T. Coate , 1992, Workfare versus Welfare: Incentive Arguments for Work Requirements in Poverty Alleviation Programs, American Economic Review, 82, pp. 249261.

Biehl, D., 1996, Zum Problem der Konnexität von Aufgaben- und Ausgabenverantwortung am Beispiel der Sozialhilfe, in: M. Jungkernheinrich and P. Klemmer (eds.), Neuordnung des Gemeindefinanzsystems, Forum Öffentliche Finanzen, Band 3, Berlin.

Brown, C. C., and W. E. Oates, 1987, Assistance to the Poor in a Federal System, Journal of Public Economics, 32, pp. 307-330.

Bundesverfassungsgericht, 1992, Urteil des Bundesverfassungsgerichts zur Bemessung des Grundfreibetrages in den Jahren 1978-1984, für 1978-1980 einschließlich des allgemeinen Tariffreibetrages, 1986, 1988 sowie 1991 vom 25.09.1992. BverfGE, 87, pp. 153-181.

Dahlby, B., 1996, Distortionary Taxation and the Design of Intergovernmental Grants, International Tax and Public Finance, 3, pp. 137-155.

Deutsche Bundesbank, 1996, Die Ausgaben für Sozialhilfe seit Mitte der Achtziger Jahre, Monatsberichte der Deutschen Bundesbank, April 1996, pp. 35-51.

Dye, R., and R. Antle, 1986, Cost Minimizing Transfer Programs, Journal of Public Economics, 30, pp. 259-263.

Feist, H., 1997, Das Bürgergeld: ein praktikabler Vorschalg für ein neues Steuer-TransferSystem?, DSWR, 26, pp. 134-138.

Gerlach, K., and G. Stefan, 1996, A Paper on Unhappiness and Unemployment in Germany, Economics Letters, 52, pp. 325-330.

Hauser, R., 1997, Armut, Armutsgefährdung und Armutsbekämpfung in der Bundesrepublik Deutschland, Jahrbücher für Nationalökonomie und Statistik, 216, pp. 523-548.

Kirbach, R., 1997, Das soziale Imperium, Die Zeit, No. 44, Oktober 24, p. 39.

Klanberg, F., and A. Prinz, 1984, Sozialhilfe im Spannungsfeld gesellschafts- und haushaltspolitischer Interessen, Wirtschaftsdienst, pp. $237 \mathrm{ff}$.

Münstermann, E., 1998, Kommunaler Finanzausgleich in den westdeutschen Ländern 1997/98. Rechtsansprüche, Richtersprüche, Restriktionen, Zeitschrift für Kommunalfinanzen, 48, pp. 74-83 and pp. 103-107.

Musgrave, R. A., 1971, Economics of Fiscal Federalism, Nebraska Journal of Economics and Business, 10, 133-172.

Nichols, A. L., and R. J. Zeckhauser, 1982, Targeting Transfers through Restrictions on Recipients, American Economic Review, 72, Papers and Proceedings, pp. 372-377.

Rosenfeld, M., 1997, Arbeit statt/und Sozialhilfe? Alternativen für einen institutionellen Neubau der sozialen Grundsicherung in Deutschland, Jahrbuch für Wirtschaftswissenschaften, 49, pp. 241-268.

Seitz, H. and C. Kurz, 1998, Arbeitslosigkeit, Zuwanderungen und Sozialhilfe: Eine Analyse der Determinanten und der Finanzierung der Sozialhilfeausgaben, Diskussionspapier 114, April, Fakultät für Wirtschaftswissenschaften der Europa-Universität Frankfurt, Oder.

Sinn, H.-W., 1994, How much Europe? Subsidiarity, Centralization and Fiscal Competition, Scottish Journal of Political Economy, 41, pp. 85-107.

Sinn, H.-W., 1997, The Selection Principle and Market Failure in Systems Competition, Journal of Public Economics, 66, pp. 247-274.

Sinn, H.-W., 1998, Der Sozialstaat in der Zwickmühle, Handelsblatt, Nr. 227, November 24, p. 53.

Strecker, E., 1995, Kommunale Haushaltsbelastung und Reformabsichten in der Sozialhilfe, Zeitschrift für Kommunalfinanzen, 45, pp. 266-271.

Wiegard, W., 1980, Distortionary Taxation in a Federal Economy, Journal of Economics, 40, pp. 183-206.

Wieland, J., 1996, Die sozialen Ausgaben der Städte/Gemeinden und ihre Finanzierung, Sozialer Fortschritt, 45, pp. 166-167.

Wildasin, D. E., 1991, Income Redistrbution in a Common Labor Market, American Economic Review, 81, pp. 757-774.

Winkelmann, L., and R. Winkelmann, 1995, Happiness and Unemployment - A Panel Data Analysis for Germany, Konjunkturpolitik, 41, pp. 293-307. 
Wrede, M., 1997, Fiskalische Ausgabenexternalitäten und die Struktur öffentlicher Ausgeben im föderalen Staat, Zeitschrift für Wirtschafts- und Sozialwissenschaften, 117, pp. 585-601

Zeckhauser, R. J., 1971, Optimal Mechanisms for Income Transfer, American Economic Review, 61, pp. 324-334. 